Joachim Osiński

\title{
PRÓBY MODERNIZACJI POZYCJI I FUNKCJONOWANIA PARLAMENTÓW W WARUNKACH KRYZYSOWYCH
}

\section{Wprowadzenie}

Zmieniające się w szybkim tempie otoczenie zewnętrzne współczesnych państw, spowodowane m.in. przez procesy integracji regionalnej, globalizację, wzrastające usamodzielnianie się dużych ponadpaństwowych podmiotów gospodarczych (KTN), jak również znaczną samodzielność i nieprzewidywalność struktur oraz mechanizmów rynkowych, szczególnie globalnego rynku finansowego, są obok procesów wewnętrznych, zachodzących w poszczególnych państwach, zasadniczymi czynnikami przyspieszającymi dostosowanie i procesy modernizacyjne samych państw. Dzieje się to stosunkowo wolno w porównaniu do zmieniających się uwarunkowań gospodarczych w wymiarze globalnym czy regionalnym zarówno w Europie, jak i w Azji. Warunki kryzysu finansowego 2007+, a następnie kryzysu ekonomicznego lat 2008-2009 powodowały większe zainteresowanie badaczy, ale także polityków, dziennikarzy i samych obywateli sferą gospodarczą, bowiem stamtąd mogły przyjść największe zagrożenia dla stabilności i rozwoju ekonomiczno-społecznego.

Dla społeczeństw, a także badaczy w naszej części Europy, z której duża liczba państw stała się członkami Unii Europejskiej od 1 maja 2004 r., było to zupełnie nowe doświadczenie. Kryzys, z którym zetknęliśmy się po kilku latach prosperity będącej rezultatem przeprowadzonej z powodzeniem transformacji systemowej, wspomaganej dodatkowo przez fundusze unijne zarówno przed rokiem 2004, jak i po nim, był pierwszym tego rodzaju doświadczeniem w nowej sytuacji politycznej i gospodarczej wielu państw Europy Środkowej. Dzięki m.in. pewnemu "Zacofaniu” naszego polskiego systemu bankowego i rynku finansowego w stosunku do „starych państw” UE stosunkowo łagodnie przetrwaliśmy najgorsze momenty wspomnianego kryzysu, w odróżnieniu od niektórych naszych sąsiadów - Łotwy, Estonii czy Węgier, których gospodarki dość bezkrytycznie otwarto na konkurencję zewnętrzną po akcesji do UE. Polska jako swego rodzaju „pasażer na gapę” potrafiła w warunkach kryzysowych wykorzystać społeczną i indywidualną przedsiębiorczość, mentalne przygotowanie społeczeństwa do kryzysu w gospodarce (doświadczenia 
realnego socjalizmu), a także pracowitość i kreatywność oraz stosunkowo dobre struktury instytucjonalne państwa dla zamortyzowania i ograniczenia negatywnych skutków kryzysu' ${ }^{1}$.

Wspomniane wydarzenia kryzysowe i ich skutki wewnętrzne i zewnętrzne dla państw europejskich spowodowały przyspieszenie refleksji na temat roli i znaczenia poszczególnych państw narodowych w warunkach kryzysu oraz niepewności (ten drugi termin zarezerwowany jest dla sytuacji w roku 2011+, bowiem nie jesteśmy jeszcze w stanie określić długości trwania tej sytuacji). „W sensie teoretycznym kryzys ekonomiczny i jego wielorakie skutki doprowadziły do ponownego, krytycznego przeanalizowania wielu twierdzeń, zaleceń czy ustaleń dokonanych w naukach ekonomicznych, naukach o zarządzaniu i finansach oraz prawie, filozofii i etyce, politologii czy socjologii. Dokonano i dokonuje się rewizji paradygmatów w teorii organizacji i zarządzania, w ekonometrii, teorii finansów oraz dyskutuje na nowo o przydatności wysoce zmatematyzowanych metod kalkulowania ryzyka w ekonomii i finansach (możliwym policzeniu wariantów niepoliczalnych, jak w przypadku wysoce skomplikowanych produktów proponowanych przykładowo przez fundusze hedgingowe). W przeszłości analityczne grupy ekspertów tworzone przez różne instytucje finansowe i globalne podmioty gospodarcze, agencje ratingowe, a także agencje państwowe, dostarczały coraz to nowych raportów o sytuacji finansów i gospodarki, pisanych coraz bardziej niezrozumiałym, hermetycznym językiem. Językiem czy raczej swoistą «nowomową», jaką posługiwali się «neoliberalni szamani od finansów», którzy przekonywali akcjonariuszy, decydentów i zwykłych obywateli do swoich poczynań oraz uzasadniali utrzymującą się przede wszystkim w USA jeszcze do końca 2007 r., «fikcję niezakłóconego rozwoju». Czas refleksji naukowej trwa i trwać będzie jeszcze przez pewien czas $\mathrm{w}$ poszczególnych dyscyplinach naukowych"2.

Jednocześnie w poszczególnych państwach podjęto szereg decyzji i działań, które mają w większym stopniu uczynić instytucję państwa bardziej skuteczną $\mathrm{w}$ warunkach kryzysu i niepewności, szczególnie gospodarczej, ale także społeczno-politycznej. Te działania i decyzje oraz zgłaszane projekty przyszłych przedsięwzięć mających na celu poprawę kondycji i statusu państwa i jego organów określam mianem „prób modernizacyjnych”. Miały i mają one w państwach europejskich najczęściej odgórny

1 Por. Raport NBP, Polska wobec światowego kryzysu gospodarczego, Warszawa 2009. Raport wskazuje na obszary, które należy udoskonalić, aby uodpornić polski system bankowy na szoki zewnętrzne w przyszłości, wśród których wyróżnia się: lepsze zarządzanie płynnością w bankach, zarządzanie ryzykiem kredytowym czy nowy kształt nadzoru bankowego.

2 J. Osiński, Niezbędność państwa $w$ dobie globalizacji oraz jego współczesne modele, w: Współczesne państwo w teorii i praktyce, red. J. Oniszczuk, Oficyna Wydawnicza SGH, Warszawa 2011, s. 677. 
charakter. Jednak w tych państwach, których społeczeństwa najdotkliwiej odczuły i odczuwają skutki kryzysu i niepewności (Islandia, Grecja, Hiszpania, Portugalia, Irlandia), bardzo wyraźny jest trend oddolny, oparty na inicjatywach związków zawodowych, organizacjach trzeciego sektora, inicjatywach obywatelskich różnych grup i środowisk społecznych itp. Niniejszy artykuł dotyczy prób modernizacyjnych odnoszących się do pozycji, roli i funkcjonowania współczesnych parlamentów, które powstają zarówno wśród badaczy w obrębie nauk społecznych, jak i w różnych środowiskach politycznych czy stowarzyszeniach obywatelskich. Ramy tekstu nie pozwalają na pełną i pogłębioną analizę zamierzeń modernizacyjnych w odniesieniu do parlamentów poszczególnych państw europejskich, są jednak wystarczające dla wskazania kierunków ewolucji, jakie wyraźnie się w tym względzie w Europie zarysowują.

\section{Ewolucja oczekiwań wobec instytucji państwa w warunkach kryzysu i niepewności}

Wspomniany kryzys finansowy, a następnie kryzys w realnej gospodarce lat 2008-2009 spowodowały pewne zmiany w percepcji społecznej, dotyczącej naszego miejsca w Europie i świecie. Wejście Polski do UE, oprócz różnych wymiernych korzyści gospodarczych i politycznych, spowodowało również powstanie impulsu mentalnego sprowadzającego się do psychologiczno-socjologicznego uznania naszej obecności w Europie. W świadomości zwykłych obywateli Polski, ale także innych państw naszego regionu zaczęło utrwalać się poczucie stabilności, bezpieczeństwa i współdecydowania o najważniejszych sprawach dotyczących Polski i Europy. Zdawano sobie sprawę $\mathrm{z}$ wyzwań, jakie przed nami stoją, ale jednocześnie społeczeństwo uzyskało jasno wytyczoną perspektywę rozwoju w różnych dziedzinach (politycznej, gospodarczej, kulturowej). Należało „jedynie” wykorzystać powstałą sytuację i w jak najkrótszym czasie, powtarzając etapy rozwojowe państw zachodniej Europy, choć w szybszym rytmie, dogonić państwa „starej” UE. To doganianie trwa również obecnie, a z obliczeń ekonomistów wynika, że potrzebujemy jeszcze 19 lat, aby doścignąć w rozwoju gospodarczym państwa Europy Zachodniej, a więc, w przybliżeniu, jednego pokolenia.

Owo bezpieczeństwo i uporządkowany rozwój zostały zachwiane i zakwestionowane przez kryzysowe wydarzenia w realnej gospodarce, które „wlały się" do Europy na początku 2008 r. Unaoczniły one wielu politykom, badaczom i zwykłym obywatelom, że są praktycznie bezsilni wobec zapaści finansowej na amerykańskim 
rynku nieruchomości, która to zapaść bardzo szybko z wirtualnych rynków finansowych poprzez sektor bankowy wkroczyła do gospodarki realnej. Odczucie, że wszystko dzieje się poza nami, że nie tylko poszczególne społeczeństwa, ale i rządy wielu państw, a nawet zinstytucjonalizowane struktury UE nie mają dostatecznych możliwości kontrolowania i kierowania żywiołowymi procesami rynkowymi, stało się rzeczywiste. Władze państw narodowych, międzynarodowe organizacje i instytucje finansowe uświadomiły sobie zakres niebezpieczeństw. Nikt nie mógł się czuć bezpieczny mimo uruchomienia ogromnych środków finansowych, od Japonii przez USA do Wielkiej Brytanii, dla ustabilizowania i odwrócenia zjawisk kryzysowych.

Współczesne państwa stanęły przed ogromnymi wyzwaniami. Nasuwa się pytanie: czy współcześnie szeregowy obywatel powinien wierzyć, że działania podejmowane przez rządy, prezydentów, parlamenty i inne organy poszczególnych państw będą skuteczne, pozwolą na oddalenie najgorszych skutków kryzysu i zasługują na zaufanie?

$\mathrm{Na}$ gruncie nauki o państwie istotna stała się ponowna analiza funkcji realizowanych przez państwo, „rozłożonych” na poszczególne jego organy i mających charakter, najogólniej rzecz biorąc, realizowanych przezeń zadań, składających się w sumie na realizację przez państwo, jako instytucję organizującą społeczeństwo do indywidualnej i zbiorowej aktywności, sensu swojego istnienia. Ważnym ponownie stało się sformułowanie odpowiedzi na pytanie: Czy państwo jest nadal w stanie zapewnić poczucie bezpieczeństwa i zdolność do rozwoju poszczególnych społeczeństw oraz czy kolejne kryzysy ekonomiczne będą wpływały na modyfikację zakresu horyzontalnego i wertykalnego funkcji (zadań) realizowanych przez współczesne państwa? A także: czy współczesne państwa modernizują się, czy też nie, bez względu na kryzysy w poszczególnych dziedzinach - gospodarcze, spoleczne, kulturowe i militarne?

Są to kwestie, jak się wydaje, obecnie podstawowe, bowiem w końcu XX wieku, szczególnie po rozpadzie bipolarnego układu międzynarodowego, sformułowano w literaturze ekonomicznej, politologicznej i socjologicznej wiele opinii wskazujących na malejące znaczenie instytucji państwa w nowej sytuacji, charakteryzującej się pewnym chaosem w przestrzeni międzynarodowej ${ }^{3}$. Chaos ten wywołał $\mathrm{z}$ jednej strony wspomniany rozpad znanego dotąd, stabilnego, przewidywalnego i dualistycznego świata, postępujące procesy globalizacji, a także nasilenie procesów integracji regionalnej. Obok malejącego znaczenia państwa jako podmiotu stosunków międzynarodowych (przejmowanie niektórych jego funkcji przez ugrupowania

${ }^{3}$ Za klasyczną w tej dziedzinie uznaje się pracę: $\mathrm{K}$. Ohmae, The end of the nation state: the rise of regional economies, New York 1995. 
integracyjne lub zglobalizowany rynek) akcentowano także zawężanie funkcji (zadań) państwa w sensie wewnętrznym, wskutek rozwoju instytucji społeczeństwa obywatelskiego oraz postępującej decentralizacji władzy i regionalizacji terytorialnej współczesnych państw ${ }^{4}$.

W warunkach kryzysu na państwo i jego organy (przede wszystkim parlament i władzę wykonawczą) spadają dodatkowe obowiązki, które polegają na budowaniu zaufania w relacjach ze społeczeństwem oraz rozsądnym unikaniu działań mogących wywołać panikę lub inne niekontrolowane zachowania poszczególnych grup obywateli, np. właścicieli depozytów bankowych, konsumentów na szczególnie wrażliwym segmencie rynku czy emerytów, obawiających się wstrzymania lub zmniejszenia w warunkach kryzysu świadczonych emerytur. Utrzymywanie przez rządzących wysokiego stopnia zaufania społecznego jest $\mathrm{w}$ takich sytuacjach absolutnie niezbędne.

W niektórych państwach udało się zachować zarówno wysoki stopień zaufania, jak i przekonanie o skuteczności wdrażanych programów państwowych zmierzających do ograniczenia skutków kryzysu. Takie wyniki podają badania socjologiczne i realne zachowania obywateli. Kryzys finansowy i idący za nim kryzys ekonomiczny spowodowały mniej lub bardziej wymuszoną reakcję państw i ich organów (szczególnie władz wykonawczych oraz parlamentów), która jednakże była oczekiwana przez obywateli i przyniosła $w$ konsekwencji pewien wzrost poczucia bezpieczeństwa i stabilności. W analizowanych państwach autorytet jego ośrodków decyzyjnych wzrósł kosztem upadku prestiżu „finansowych szamanów” oraz spadku zaufania do instytucji finansowych, w tym banków. Nie dotyczy to jednak wszystkich państw. Sytuacja wyjściowa wielu krajów była bardzo różna (np. Islandia, Grecja, Hiszpania czy Irlandia), co w skrajnych przypadkach kończyło się ogłoszeniem niewypłacalności (Islandia) lub faktycznym bankructwem państwa, bez formalnego ogłoszenia tego faktu (Grecja).

Takie były i są naturalne reakcje społeczeństw w warunkach kryzysu - „instytucja państwa, mimo całego wobec niego krytycyzmu, jest symbolem stabilności i bezpieczeństwa, czego trudno nie zauważyć (nota bene w Chinach, jak wynika z badań, dało się to odczuć w największym stopniu). Dla obywateli mniejsze znaczenie ma fakt, iż niektóre z banków zwróciły już pomoc finansową, którą otrzymały od państwa, wraz z należnymi odsetkami, np. Goldman Sachs, i że w sumie

4 Opinie dotyczące zjawiska „internacjonalizacji polityki wewnętrznej” i problemu tzw. rozrzedzenia państw, spowodowanego wzrostem kontaktów międzyregionalnych (m.in. euroregionów), można łatwo odnaleźć w pracach: R.O. Keohane’a, J.S. Nye’a, E. Morse’a czy R. Holtona - przedstawicieli neoliberalnego instytucjonalizmu. Krytycznie wobec nich por. J. Osiński, Niezbędność państwa $w$ dobie globalizacji..., op.cit., s. 678. 
w 2009 r. banki w USA zwróciły państwu 115 mld dolarów długu wraz z odsetkami. W Stanach Zjednoczonych bezpośrednią pomoc finansową państwa otrzymało 540 banków na sumę ponad 400 mld dolarów. Jednak dopiero przyszłość pokaże, czy banki znów nie sięgną do kieszeni podatników"'. Obecny dziś problem i tak pozostanie, bowiem w dotychczasowej historii państwa nigdy nie zadłużyły się na tak dużą skalę zarówno u swoich obywateli, jak i wierzycieli zewnętrznych.

Reasumując, we wszystkich analizowanych przypadkach w Europie, Azji i Ameryce państwo jako główna instytucja odgrywa aktywną rolę, angażując znaczne środki finansowe i stabilizując sytuację w gospodarce i społeczeństwie. „Jednocześnie różne organy państwa (wykonawcze i prawodawcze na różnych szczeblach) usiłują tworzyć warunki dla zwiększenia bezpieczeństwa i zaufania obywateli do instytucji państwa, przy czym szczególnie akcentuje się działania zmierzające do tworzenia nowych miejsc pracy (USA). W niektórych państwach (Chiny, Japonia) wykorzystuje się w celu poprawy wizerunku systemu bankowego (finansowego) i uspokojenia sytuacji również media i organizacje pozarządowe. Mimo iż wzmożona aktywność organów państwa spowodowana została warunkami kryzysu, to jednak trudno ocenić, czy w przyszłości, gdy wróci dobra koniunktura, organy te dobrowolnie zrezygnują z obecnych możliwości nadzoru i kontroli, przede wszystkim instytucji finansowych"'.

Obywatele w warunkach kryzysu oczekują aktywności państwa $w$ wielu dziedzinach, w tym takich, co do których w stabilnym okresie pozbawionym wstrząsów gospodarczych zgłaszaliby wątpliwości, a nawet protestowali przeciwko nim. Dotyczy to szczególnie gospodarki, z szeroko pojętą sferą przedsiębiorczości, oraz społeczeństwa obywatelskiego. Zdecydowanie większą wagę społeczeństwo, ale i politycy przykładają do procedur stanowienia prawa, jego przestrzegania i egzekwowania odpowiedzialności za działania niezgodne z prawem. Szczególnie krytycznie oceniani są pod tym względem funkcjonariusze publiczni, przedsiębiorcy oraz osoby związane z systemem bankowym i finansowym ${ }^{7}$.

Dlatego też sądzę, że określenie „funkcja ekonomiczna” (zakreślona przez zagadnienia analizowane na gruncie nauk ekonomicznych) lub jeszcze lepiej - „funkcja

\footnotetext{
5 Państwa narodowe wobec kryzysu ekonomicznego, red. J. Osiński, Oficyna Wydawnicza SGH, Warszawa 2010, s. 11-12.

6 Ibidem, s. 164-165.

7 Przypadek Islandii nie jest może najbardziej typowy i miarodajny, jednak należy podkreślić, iż stopniowo osoby, które swoimi działaniami lub zaniechaniami doprowadziły do katastrofy islandzkiego systemu bankowego i gospodarki, pociągane są do odpowiedzialności karnej (np. prezesi banków, wysocy urzędnicy państwowi). Premier rządu islandzkiego w okresie poprzedzającym kryzys i w początkach jego rozprzestrzeniania się w gospodarce, Geir H. Haarde, został postawiony przed Sądem Stanu (Trybunałem Stanu) na podstawie art. 14 Konstytucji Islandii. Szerzej patrz: J. Osiński, Przemiany polityczne na Islandii w warunkach kryzysu bankowego i gospodarczego, „Kwartalnik Kolegium Ekonomiczno-Społecznego. Studia i Prace", Oficyna Wydawnicza SGH, Warszawa 2011, nr 1(5), s. 13-45.
} 
ekonomiczno-finansowa" (akcentująca we współczesnej rzeczywistości globalnej, ale i w konkretnych państwach narodowych wymiar finansowy działalności gospodarczej) wydaje się znacznie bliższe wszechstronnej oraz rzeczywistej aktywności państwa w dziedzinie produkcji i wymiany towarów i usług, kreowania i kontrolowania rynków finansowych, prowadzenia polityki gospodarczej i pieniężnej itp. ${ }^{8}$ Znacznie lepiej i trafniej pozwala ono analizować współczesną rzeczywistość niż tradycyjnie wyróżniana i opisywana w opracowaniach funkcja gospodarcza czy gospodarczo-organizatorska państwa.

Czy jeśli w warunkach kryzysu ekonomicznego państwo zagwarantuje swoim obywatelom wypłacalność depozytów bankowych do pełnej wysokości (co stało się w wielu państwach w 2008 r.), to rzeczywiście właściwe będzie stwierdzenie, że było to działanie w ramach funkcji gospodarczo-organizatorskiej państwa? Czy nie jest widoczny anachronizm takiej konstatacji, przynajmniej na gruncie nauk ekonomicznych? Nie sposób trwać przy dotychczasowych utartych określeniach. W większości europejskiej lub amerykańskiej literatury przedmiotu konstrukcje teoretyczne $\mathrm{z}$ połowy XX wieku zarzucono ponad dwadzieścia lat temu', to jest $\mathrm{w}$ czasach, kiedy w naszej części Europy rozpoczynał się proces transformacji systemowej. Był to wówczas najważniejszy temat dla naszej refleksji naukowej w politologii, ekonomii czy naukach prawnych. Dziś jesteśmy w sytuacji znacznie bardziej komfortowej i powinniśmy bezzwłocznie zapoznać się i oswoić z nowymi, dynamicznie rozwijającymi się propozycjami metodologicznymi (neoinstytucjonalizm) i zasadniczymi konstatacjami we współczesnej teorii państwa. W warunkach trwających od kilkudziesięciu lat burzliwych zmian w dziedzinie techniki, technologii oraz organizacji i zarządzania procesami wytwórczymi i wymiany, zwiększającego się udziału usług w kreowaniu poziomu rozwoju gospodarek narodowych, a także regionalizowania się i globalizowania rynków - gwałtownego wzrostu globalnego rynku usług i globalnego rynku finansowego - używanie podobnych terminów dla określenia istotnej funkcji współczesnego państwa jest anachronizmem. Tutaj również „modernizacja terminologiczna" jest niezbędna.

Sadzę także, iż wyróżnianą powszechnie funkcję zewnętrzną państwa i jej realizację należy zróżnicować przestrzennie, od poziomu najbliższego otoczenia

\footnotetext{
${ }^{8}$ Istocie współczesnego państwa poświęcam rozdział Niezbędność państwa $w$ dobie globalizacji oraz jego współczesne modele, w: Współczesne państwo w teorii i praktyce..., op.cit., s. 649-716. Powyższe uwagi odnoszą się do trudności, jakie można napotkać, udzielając odpowiedzi na jedno z zasadniczych pytań tego artykułu: czy kryzysy ekonomiczne mają istotne znaczenie dla modernizacji instytucji państwa?

9 Por. D. Held, Political theory and the modern state, Polity Press, Cambridge 1989; Political theory today, red. D. Held, Polity Press, Cambridge 1991 (szczególnie rozdział: Democracy, nation-state and the global system); Formation of modernity, red. D. Hall, B. Gieben, Polity Press, Cambridge 1992 (szczególnie rozdział: The development of the modern state $\mathrm{i}$ inne).
} 
międzynarodowego (sąsiadów), poprzez aktywność w ramach regionalnych ugrupowań integracyjnych (Unia Europejska, Unia Afrykańska itd.), do uczestnictwa w działaniach mających wymiar globalny (np. udział państw w pomocy rozwojowej czy interwencjach wojskowych i pomocy humanitarnej). Pozwoli to na bardziej precyzyjne i zgodne z rzeczywistością badanie i obserwowanie zwiększania się zakresu podmiotowego i przestrzennego aktywności zewnętrznej państw. Niektórzy badacze (np. J. N. Rosenau, U. Beck i E. Grande) idą jeszcze dalej, wskazując, że dotychczasowe, klasyczne granice między polityką wewnętrzną i zewnętrzną (zagraniczną) zacierają się i rozmywają. Stąd samo rozróżnianie w warunkach integracji, a szczególnie nasilającej się globalizacji, „wnętrza” i ,zewnętrza” także wydaje się anachroniczne ${ }^{10}$.

Przedstawione zagadnienia pozwalają, jak sądzę, sformułować w pewnym zakresie odpowiedź na pytanie: czy kolejne kryzysy ekonomiczne wpływają na modyfikację zakresu horyzontalnego i wertykalnego aktywności państwa lub inaczej, funkcji realizowanych przez współczesne państwa i ich organy wewnętrzne, w tym parlamenty i rządy? Można zasadnie stwierdzić, iż kryzys finansowy 2007+ spowodował rozszerzenie zakresu aktywności państwa w niektórych dziedzinach, szczególnie tych związanych $\mathrm{z}$ problemami ekonomicznymi oraz zapewnieniem bezpieczeństwa socjalnego i finansowego obywateli. W pierwszym przypadku państwa uruchomiły różne programy pomocowe i konsolidacyjne dla zagrożonych bankructwem przedsiębiorstw i banków, dzięki którym zdecydowana większość z nich powoli wraca lub powróciła do normalnego funkcjonowania. Państwa przeciwstawiły się także skrajnej deregulacji gospodarki, dokonywanej najczęściej w warunkach dobrej koniunktury gospodarczej, w szczególności tej dotyczącej banków i instytucji finansowych, a także rynków finansowych. W wielu państwach wprowadzono w tych dziedzinach nowe regulacje prawne zapewniające nadzór i możliwość przewidywania negatywnych zjawisk i przeciwdziałania im, a także podjęto $\mathrm{w}$ ramach G20 próby stworzenia globalnych zasad i procedur dotyczących rynków finansowych. O ich skuteczności i efektywności przekonamy się w warunkach ewentualnego kolejnego kryzysu, czyli za kolejne 8-10 lat, a być może wcześniej.

Dodatkowo państwa w różny sposób wspomagały obywateli, poszczególne grupy zawodowe i społeczne, które znalazły się w trudnej sytuacji w warunkach kryzysu. Dotyczy to m.in. gwarancji dla depozytów i oszczędności obywateli, które znalazły się w bankach i innych instytucjach finansowych (np. w firmach ubezpieczeniowych) narażonych na upadek. Można więc stwierdzić, iż poszczególne „państwa bronią w obecnym kryzysie swoich obywateli, podejmując różne działania mające na celu

10 Interesującą syntezę poglądów na ten temat przedstawia praca: S. Bieleń, Państwa w stanie kryzysu i upadku?, w: Państwo w teorii i praktyce stosunków międzynarodowych, red. M. Sułek, J. Symonides, Wyd. Uniwersytetu Warszawskiego, Warszawa 2009, s. 49-50. 
uporządkowanie rynków finansowych i podejmują decyzje gwarantujące bezpieczeństwo oszczędności obywateli zgromadzonych w bankach i innych instytucjach finansowych. $Z$ drugiej strony, władze poszczególnych państw wspomagają instytucje finansowe oraz niektóre strategiczne przedsiębiorstwa w trudnym dla nich momencie i dotyczy to także tych uznawanych dotąd za skrajnie liberalne"11.

Należy jednak podkreślić, iż owe horyzontalne i wertykalne zmiany w aktywności instytucji państwa spowodowane kryzysem mają charakter krótkookresowy (dotyczy to państw normalnie funkcjonujących $\mathrm{w}$ przestrzeni wewnętrznej i zewnętrznej, nie zaś państw upadłych, upadających, pogrążonych w chaosie, quasi-państw czy państw lilipucich, które są najczęściej geopolitycznymi bytami terytorialnymi o sztucznym charakterze ${ }^{12}$ ). Nie leży w istocie państwa rozciąganie owych nadzwyczajnych działań i interwencji w czasie, ponad ten jedynie niezbędny dla wprowadzenia stabilności i bezpieczeństwa w sferach gospodarki i finansów oraz ochrony obywateli. Instytucja państwa ma sprzyjać tworzeniu optymalnych warunków rozwoju cywilizacyjnego ( $w$ tym poprawy bytu społeczeństwa i rozwoju technologicznego sfery materialnej), co nie oznacza, iż powinna tego dokonywać sama. Musi liczyć na współdziałanie i synergię wynikającą z uczestnictwa w procesach rozwojowych innych struktur i podmiotów, w tym m.in. struktur i mechanizmów rynku. Tak więc w długim okresie państwo pozostaje w różnym stopniu i w różnych zakresach realizatorem swojej istoty i zasadniczego celu, jakim jest rozwój cywilizacyjny społeczeństw, dokonując korekty instrumentów związanych z optymalizacją dążenia do realizacji tego celu.

W odpowiedzi na inne pytanie, a mianowicie: czy współczesne państwa modernizują się bez względu na kryzysy w poszczególnych dziedzinach (gospodarczej, społecznej, kulturowej czy militarnej), czy też podobne kryzysy wykluczają procesy modernizacji instytucji państwa? - należy podkreślić, iż modernizacja państwa dokonuje się autonomicznie, a nawet niezależnie od występujących periodycznie zjawisk kryzysowych. Procesy modernizacji instytucji państwa rozumianej ontologicznie trwają od wieków, nawet jeśli ograniczymy nasze spostrzeżenia do czasów, kiedy ukształtowały się współczesne państwa narodowe. Przebiegały one zazwyczaj w skomplikowanych warunkach pełnych napięć, konfliktów, wojen i kataklizmów naturalnych. Dokonywały się w trakcie obu wojen światowych, które uznać należy za sytuacje skrajnie kryzysowe, kiedy dokonywała się wspomniana już zmiana zakresu

${ }^{11}$ J. Osiński, Nauka o państwie wobec wspótczesnego kryzysu finansowego, w: Nauki społeczne wobec kryzysu na rynkach finansowych, red. J. Osiński, S. Sztaba, Oficyna Wydawnicza SGH, Warszawa 2009, s. 99.

12 Por. np. M. Kosienkowski, Quasi-państwo w stosunkach międzynarodowych, „Stosunki Międzynarodowe - International Relations” 2008, t. 38, nr 3-4; M. Sobczyński, Państwa i terytoria zależne: ujęcie geograficzno-polityczne, Wyd. Adam Marszałek, Toruń 2006. 
aktywności instytucji państwa, podporządkowująca niemal wszystko uczestnictwu w działaniach wojennych zmierzających, w przypadku Aliantów, do zwycięskiego zakończenia.

Reasumując, modernizacja instytucji państwa rozumianego ontologicznie (to jest nieutożsamianego $\mathrm{z}$ jakimś konkretnie istniejącym współcześnie państwem) następuje niezależnie od warunków kryzysowych. Modernizacji ulegają $\mathrm{w}$ różnym stopniu również organy wewnętrzne państwa. Wynika to $\mathrm{z}$ jego istoty jako instytucji celowej, spełniającej określone powinności wobec społeczeństwa, w tym gwarantującej mu warunki do życia, bezpieczeństwa i wszechstronnego rozwoju. Oczywiście, sytuacje kryzysowe realizacji takich działań nie ułatwiają i im nie sprzyjają, ale warunki korzystne właściwie spożytkowane pozwalają ewentualne spowolnienia zminimalizować. Dodać jednak należy, iż w krótkich okresach czasu konkretne państwa rządzone przez dyktatorów, uzurpatorów czy szaleńców mogą pod wpływem dyktatorskich wizji i urojeń przejawiać swoją aktywność nawet $\mathrm{w}$ kierunkach sprzecznych czy niezgodnych $\mathrm{z}$ teleologiczną istotą państwa. Może wówczas nastąpić swoiste „cofnięcie się” danego społeczeństwa w rozwoju cywilizacyjnym. Jednak podkreślmy, że dotyczy to krótkich dziejowo okresów, po których sytuacja, podobnie do wahadła zegara, powraca w położenie zgodne z istotą państwa.

\section{Parlamenty w warunkach kryzysu ekonomicznego}

Wraz z nasilaniem się sytuacji kryzysowej od końca 2007 r. parlamenty stały się instytucjami, które zaczęły być surowiej oceniane przez część polityków, przedsiębiorców, badaczy czy zwykłych obywateli. Dotyczyło to wówczas przede wszystkim Kongresu Stanów Zjednoczonych, a nieco później brytyjskiej Izby Gmin, francuskiego Zgromadzenia Narodowego czy japońskiej Izby Reprezentantów. Wynikało to z roli, jaką przyszło odegrać parlamentom w pierwszych miesiącach kryzysu finansowego 2007+. Polegała ona na często bezkrytycznym aprobowaniu przygotowanych przez władze wykonawcze planów pomocowych dla największych banków i instytucji finansowych. Przykładem jest w USA tzw. plan Paulsona - sekretarza Departamentu Skarbu (tzw. Troubled asset relief programme, TARP) został uchwalony przez Kongres przy wystąpieniu przynajmniej kilku paradoksalnych okoliczności. „Jak przyznał w wywiadzie dla «Washington Post» Neel Kashkari, asystent ówczesnego Sekretarza Departamentu Skarbu, który w rzeczywistości był twórcą planu, liczba $700 \mathrm{mld}$ dol., która pojawiła się w TARP była dość przypadkowa. Skalkulował bowiem, iż w USA było wówczas 
11 bln dol. kredytów hipotecznych i 3 bln dol. kredytów komercyjnych, czyli łącznie 14 bln dol., zaś 5\% tej sumy stanowiło «okrągłą sumkę» 700 mld dol., jakie zawarte zostały w planie. Dlaczego 5\%? N. Kashkari przyznaje: «wziąłem to z sufitu, trzeba było wyciągnąć jak najwięcej od Kongresu, a 1 bln wydawało się zbyt dużo». Same głosowania w Kongresie też doczekały się «swoich» opracowań, wskazujących, że nikt tak naprawdę nie wiedział do końca, co się dzieje i za czym głosuje, a decyzje podejmowano w pośpiechu pod naciskiem chwili i niemożliwych do przewidzenia skutków sytuacji. Po prostu, politycy jeszcze nie tak dawno piętnowani przez finansistów za brak skuteczności i traktowani przez nich instrumentalnie, musieli ratować międzynarodowy system bankowy"13.

Uchwalenie wspomnianego aktu w Kongresie USA miało też swoją pouczającą historię. Ustawa nosiła tytuł Emergency economic stabilization act of 2008, a potocznie była znana jako "plan ratunkowy systemu finansowego USA” i upoważniała sekretarza Skarbu do przeznaczenia funduszy na programy wspierające amerykański sektor bankowy, będący już wówczas (wrzesień 2008 r.) w poważnym kryzysie. W ramach programów miały zostać skupione niektóre „toksyczne aktywa” („toxic assets") banków, co miało doprowadzić do ustabilizowania rynku finansowego i zminimalizowania problemów w realnej gospodarce Stanów Zjednoczonych, a równocześnie poprzez takie działania miały zostać ochronione środki finansowe podatników. Koszty takich działań oszacowano „z kapelusza” na 700 mld dol., a cały pierwotny projekt ustawy liczył 3 strony!, co wskazywało, iż w Departamencie Skarbu, ale także w innych agendach administracji Georga Busha nie do końca zdawano sobie sprawę z powagi sytuacji. Jak dotąd bowiem, zgodnie z dominującą doktryną ekonomiczną, rynki same rozwiązywały powstałe na nich problemy, a interwencja państwa w takiej skali była nie do pomyślenia. Tym razem jednak chodziło o „ratowanie” banków, a nie „przeszkadzanie” im w nieskrępowanej działalności.

Projekt ustawy, a w zasadzie poprawkę do niej, znacznie rozszerzająca zakres możliwych interwencji Departamentu Skarbu i licząca w momencie głosowania 110 stron, poddano pod głosowanie w Izbie Reprezentantów 29 września 2008 r. i odrzucono w głosowaniu stosunkiem głosów 228 przeciw, $205 \mathrm{za}^{14}$. Inicjatywa

13 Państwa narodowe wobec kryzysu ekonomicznego..., op.cit., s. 162-163. Por. także: W. Nawrot, Globalny kryzys finansowy XXI wieku: przyczyny, przebieg, skutki, prognozy, CeDeWu.pl Wydawnictwa Fachowe, Warszawa 2009, szczególnie rozdział 5 Krajowe i międzynarodowe interwencje rządowe w odpowiedzi na kryzys finansowy, s. 129-158.

14 Por. Final vote results for roll call 674, za: http://clerk.house.gov/evs/2008/roll674.xml (dostęp: 29 września 2008). 
ustawodawcza, zawierająca poprawiony po zastrzeżeniach Izby Reprezentantów projekt ustawy, została zgłoszona ponownie, tym razem $\mathrm{z}$ wykorzystaniem Senatu ${ }^{15}$. Po burzliwej debacie projekt uzupełniono o szereg dodatkowych klauzul (m.in. zwiększono gwarantowaną przez The Federal Deposit Insurance Corporation (FDIC) kwotę depozytów ze 100 tys. do 250 tys. dol. na depozytariusza), powiększając całkowity koszt planu o ok. 150 mld dol., a wielkość tekstową samego projektu do ponad 450 stron. Tak poprawiony projekt ustawy w stosunku do wersji pierwotnej poddano pod głosowanie 1 października 2008 r. i Senat USA większością głosów 74 do 25 przyjął projekt. Następnie przesłano go niezwłocznie do Izby Reprezentantów, która po rozpatrzeniu w dniu 3 października 2008 r. uchwaliła dokument stosunkiem głosów 263 do $171^{16}$. Po podpisaniu przez prezydenta ustawa mogła wejść $\mathrm{w}$ życie i stanowiła podstawę wspomnianego programu TARP.

Wbrew panującej w literaturze ekonomicznej opinii to jednak nie amerykańska władza wykonawcza była inicjatorem najwcześniejszego i największego planu ratowania banków, przygotowanego w Departamencie Skarbu w administracji Georga Busha i przyjętego przez Kongres USA. Znacznie wcześniej podobną decyzję musiał podjąć parlament Japonii na wniosek rządu, który trafił do Izby Reprezentantów parlamentu (Kokkai) ${ }^{17}$ w sierpniu 2008 r. To parlament Japonii przyjął ,jako pierwszy pakiet stabilizacyjno-stymulacyjny w sierpniu 2008 r. (120 mld dol.), następny w październiku 2008 r. (260 mld dol.), kolejny, największy, w grudniu 2008 r. (400 mld dol.), co w sumie daje prawie 800 mld dol. w roku 2008. W programach przyjętych w 2009 r. w kwietniu i grudniu było to odpowiednio, $600 \mathrm{mld}$ i $110 \mathrm{mld}$ dol. Są to do tej pory największe środki «antykryzysowe» spośród państw świata, zarówno w relacji do PKB, jak i w wielkościach bezwzględnych"18.

$\mathrm{Z}$ drugiej strony, kiedy kryzys zaczął „rozlewać się" w amerykańskim systemie bankowym w drugiej połowie 2007 r., badacze, ekonomiści i politycy „przypomnieli” Kongresowi jego wcześniejsze decyzje, które - jak się okazało - stały się prawnymi katalizatorami kryzysu na rynku kredytów subprime. Ze szczególnie krytykowanych decyzji ustawodawczych Kongresu USA należy wspomnieć przynajmniej o dwóch. Pierwsza pochodzi z 1977 r., czyli z czasów prezydentury Jimmy’ego

15 Por. US Senate Committee on Banking, Housing and Urban Affairs, The emergency economic stabilization act of 2008, za: http://banking.senate.gov/public/index.cfm?Fuseaction=Articles. Detail\&Article_id=76blaea4-39b8-404f-b3cd-f8b6c46e3b14\&Month=10\&Year=2008.

16 Por. US Senate Committee on Banking, Housing and Urban Affairs, Summery of the emergency economic stabilization act of 2008, October 2008.

17 Kokkai to nazwa własna parlamentu Japonii, który - zgodnie z Konstytucją Japonii z 3 listopada 1946 r. (data promulgacji przez cesarza Shöwa (Hirohito)) i z 3 maja 1947 r. (wejście w życie konstytucji) składa się z dwóch izb: Izby Reprezentantów - Shugi-in oraz Izby Radców - Sangi-in.

18 Państwa narodowe wobec kryzysu ekonomicznego..., op.cit., s. 162. 
Cartera. Uchwalona wówczas ustawa Community reinvestment act (CRA) zobowiązywała banki do udzielania kredytów osobom fizycznym i biznesowi w hrabstwach i municypalitetach, które charakteryzowały się niskimi dochodami mieszkańców. O tym, że zagadnienie to demokraci traktowali priorytetowo, świadczy fakt, iż nadzór nad realizacją przez poszczególne banki przepisów ustawy powierzono 12 regionalnym bankom rezerwy federalnej. „Od tej pory każdy bank komercyjny jest na bieżąco rozliczany z tego, komu i jakich kredytów udziela, a w szczególności, jaki jest udział w jego akcji kredytowej kredytów dla grup o niskich i średnich dochodach i mniejszości etnicznych. Na udzielających kredytów hipotecznych zostają nałożone obowiązki sprawozdawcze pozwalające lokalnym samorządom na kontrolowanie realizacji «misji» i raportowanie do banków rezerwy federalnej przypadków nie wypełniania zobowiązań wynikających z CRA"19.

Drugim przykładem było uchwalenie w 1999 r., a więc również w czasach sprawowania prezydentury przez kandydata Partii Demokratycznej (Billa Clintona), ustawy Gramm-Leach-Bliley act, która zastąpiła inną ustawę prywatną Glass-Steagall act, obowiązującą jeszcze od 1933 r. Istotą dotychczasowej ustawy było ścisłe rozdzielenie bankowości komercyjnej (detalicznej) i inwestycyjnej ${ }^{20}$. Banki komercyjne miały prawo kolekcjonowania depozytów i udzielania kredytów, a ich działalność - przede wszystkim ze względu na ochronę interesów depozytariuszy - podlegała nadzorowi banku centralnego (FED). Banki inwestycyjne finansowały swoje aktywa (wśród których były produkty finansowe obarczone zresztą znacznym ryzykiem utraty wartości) emisją własnych papierów dłużnych, a sam nadzór nad nimi był ograniczony ze strony instytucji stanowych lub federalnych. Banki komercyjne nie mogły, zgodnie z ustawą, posiadać żadnych firm finansowych. Nowa ustawa „nazywana ustawą o modernizacji usług finansowych wprowadziła znaczącą deregulację rynku usług finansowych, bankowych i ubezpieczeniowych oraz rynku papierów wartościowych. Banki komercyjne, inwestycyjne i firmy ubezpieczeniowe za pomocą firm specjalnego przeznaczenia (SPC, SPV, SIV) mogły się w pełni zaangażować w rynek kredytów hipotecznych. Rok 1999 to początek eskalacji rozwoju rynku kredytów hipotecznych"21.

19 B. Samojlik, Kryzys finansowy: źródła, skutki, kierunki naprawy, w: Nauki społeczne wobec kryzysu na rynkach finansowych, red. J. Osiński, S. Sztaba, Oficyna Wydawnicza SGH, Warszawa 2008, s. 61. Należy dodać, że w stosunku do banków winnych dyskryminacji wspomnianych grup kredytobiorców inna ustawa, tzw. Equal credit opportunity act, przyjęta nieco później, przewidywała określone sankcje finansowe i administracyjne.

20 Por. F.S. Mishkin, Ekonomika pieniądza, bankowości i rynków finansowych, przeł. A. Mincewicz, Fundacja Edukacyjna Przedsiębiorczości, Wyd. Naukowe PWN, Warszawa 2002, s. 350.

${ }^{21}$ B. Samojlik, Kryzys finansowy: źródła, skutki, kierunki naprawy..., op.cit., s. 63. 
Obie ustawy uchwalone przez Kongres w okresie władzy demokratów były elementami realizacji ich programu zmierzającego do stworzenia warunków do posiadania domu przez nisko- i średniozamożne amerykańskie rodziny. Jego początków niektórzy poszukują w 1938 r., kiedy na mocy poprawki do ustawy National housing act of 1934 powołano do życia organizację rządu federalnego pod nazwą Federal National Mortgage Association (tzw. Fannie Mae), mającą realizować misję władz federalnych w dziedzinie mieszkalnictwa. Drugą organizację o zbliżonych celach, Government National Mortgage Association (tzw. Ginnie Mae), założono w $1968 \mathrm{r}$. W 1970 r. otworzono kolejną firmę - The Federal Home Loan Mortgage Corporation, o statusie przedsiębiorstwa sponsorowanego przez rząd federalny (GSE), czyli tzw. Freddie $\mathrm{Mac}^{22}$.

Reasumując, Kongres USA, realizując obietnice wyborcze i programy demokratów, ale także republikanów (w 2002 r. George Bush ogłosił, że celem jego i republikanów jest doprowadzenie do wybudowania 5,5 mln domów przez Amerykanów do 2010 r. ${ }^{23}$, stworzył prawne warunki do powstania znacznych problemów na rynku kredytów hipotecznych, które w konsekwencji zachwiały na kilka lat rynkami finansowymi. Spowodowało to brak przewidywalności i przypadkowość i przyczyniło się do spekulacji finansowych na niespotykaną dotąd skalę. Lobby bankowo-finansowe różnymi sposobami prawnymi i pozaprawnymi wpływało na kongresmanów, aby uzyskać korzystne dla siebie rozstrzygnięcia ustawowe. Mimo iż na liczne wnioski osób fizycznych i firm budowlanych Senat USA powołał na przełomie 2007 i 2008 r. specjalną komisję przeprowadzającą tzw. przesłuchania publiczne (public hearings) osób ze świata biznesu i konsumentów, którzy utracili zdolność do spłacania kredytów hipotecznych, to jednak było już za późno, aby odwrócić toczące się niekorzystne wydarzenia na rynku kredytów subprime czy też podjąć próbę naprawienia wcześniejszych ewidentnych niekiedy pomyłek legislacyjnych.

Od początku 2008 r., a więc na długo przed 15 września, kiedy ogłoszono upadłość banku Lehman Brothers Holdings Inc., parlamenty wszystkich liczących się państw UE były i nadal są zaangażowane w ochronę banków i instytucji finansowych przed krachem ekonomicznym. Podejmowane od przełomu 2007 i 2008 r. działania

22 Ibidem, s. 59-60.

23 Dla klarowności wywodu dodajmy, że Alan Greenspan, były szef zarządu Rezerwy Federalnej, znany ze swoich prorepublikańskich poglądów, ze względu na nasilającą się recesję w gospodarce USA na przełomie lat 1999 i 2000 i malejące szanse kandydata republikanów George’a Busha w wyborach prezydenckich, doprowadził do obniżenia docelowej stopy procentowej rynku międzybankowego. Od stycznia $2000 \mathrm{r}$. do lipca 2003 r. stopa została obniżona z 6,5\% do 1\%, czyli najniższego poziomu od 45 lat. Nastąpił okres taniego i łatwego pieniądza, bowiem w nowej sytuacji realna stopa procentowa FED (stopa nominalna minus inflacja) stała się ujemna. Szerzej patrz: B. Samojlik, Polityka monetarna Rezerwy Federalnej w warunkach kryzysu, w: Wymiary kryzysu: między praktyczną teoriq a wirtualną praktyką, red. J. Osiński, Oficyna Wydawnicza SGH, Warszawa 2009, s. 79-96. 
są wspólnymi przedsięwzięciami władzy wykonawczej (prezydentów i rządów) i parlamentów, przy znacznym udziale banków centralnych poszczególnych państw (np. Bank of England lub Bank Królestwa Szwecji) i Europejskiego Banku Centralnego $(\mathrm{EBC})^{24} \mathrm{w}$ odniesieniu do państw Unii Gospodarczej i Walutowej. Również sama Unia Europejska ${ }^{25}$ i Międzynarodowy Fundusz Walutowy ${ }^{26}$ podjęły pewne działania na szczeblu regionalnym - europejskim $\mathrm{w}$ uzgodnieniu ze sobą lub równolegle za aprobatą drugiej strony. W niniejszym opracowaniu zanalizowane zostaną jedynie najbardziej charakterystyczne działania podjęte przez władze wykonawcze i parlamenty poszczególnych państw we współpracy z bankami centralnymi, zaś kwestie udziału innych $\mathrm{z}$ wymienionych podmiotów potraktowane zostaną jedynie jako egzemplifikacja wybranych problemów.

Formy udziału władz wykonawczych (rządów, prezydenta) i parlamentów we współpracy $z$ bankami centralnymi we wspomaganiu sektora bankowego były zróżnicowane $\mathrm{w}$ poszczególnych państwach i miały miejsce $\mathrm{w}$ różnych okresach w zależności od rozwoju zjawisk kryzysowych w danym państwie. W 2008 r. znaczna część polityków i ekonomistów w poszczególnych państwach była przekonana, iż w celu ustabilizowania systemu bankowego i zapobieżenia jego rozpadowi konieczne było „po pierwsze - wyeliminowanie ryzyka (w krótkim terminie) niewypłacalności banków, w wyniku niemożności zrefinansowania zadłużenia na rynku międzybankowym. W tym celu zdecydowano się po pierwsze, na działania interwencyjne w zakresie podtrzymania płynności na rynkach finansowych oraz wprowadzono gwarancje spłaty zobowiązań banków. Po drugie, niezbędnym stało się ograniczenie ryzyka niewypłacalności (w krótkim okresie) banków z powodu szturmu klientów w celu wycofania depozytów, wobec czego postanowiono o wprowadzeniu zmian w systemie gwarantowania depozytów. Po trzecie, konieczne stało się ograniczenie działania czynników wzmagających obawy o możność przetrwania banków, dlatego wprowadzono ograniczenia w tzw. krótkiej sprzedaży. Po czwarte, istniała pilna potrzeba ustabilizowania sektora finansowego w średnim terminie poprzez usunięcie negatywnych czynników destabilizujących i wprowadzających nieufność, dlatego też postanowiono o przejęciu przez państwo toksycznych aktywów oraz o uzupełnieniu bufora bezpieczeństwa w drodze dokapitalizowania banków.

\footnotetext{
24 Por. np.: L. Oręziak, Strefa euro wobec kryzysu gospodarczego, w: Unia Europejska wobec kryzysu ekonomicznego, red. J. Osiński, Oficyna Wydawnicza SGH, Warszawa 2009, s. 119-130.

25 Por. np.: I. Zawiślińska, Wsparcie sektora finansowego $w$ Stanach Zjednoczonych $i$ wybranych państwach Unii Europejskiej w warunkach globalnego kryzysu, w: Wymiary kryzysu..., op.cit., s. 97-112.

26 Por. np.: E. Latoszek, Działania MFW na rzecz stabilizowania międzynarodowych finansów, w: Nauki społeczne wobec kryzysu ekonomicznego..., op.cit., s. 45-66.
} 
W końcu niezbędne było pobudzenie rynku kredytowego oraz zmniejszenie kosztów obsługi zadłużenia, wobec czego zdecydowano się na obniżki stóp procentowych"27.

Dokonując podobnej analizy z perspektywy ekonomicznej, należy postawić pytanie: czy rzeczywiście z punktu widzenia zwykłego obywatela wszystkie zaproponowane działania władz wykonawczych i parlamentów oraz banków centralnych były uzasadnione? Kolejne miesiące trwania kryzysu wskazują, że podjęcie niektórych z nich „zdjęło” z banków i instytucji finansowych odpowiedzialność za podejmowane niezwykle ryzykowne przedsięwzięcia biznesowe. Szczególnie czwarty z podejmowanych kierunków działań (m.in. przejęcie przez państwa toksycznych aktywów) musi budzić sprzeciw. Zwalnia bowiem z odpowiedzialności zarządy i dyrektorów banków, którzy realizowali określone strategie udzielania kredytów i zarządzali ryzykiem swoich firm. Kredyty ninja i idące w ślad za nimi papiery dłużne zabezpieczone hipotecznie - CDO (collateralized debt obligation), będące efektem sekurytyzacji (zamiany na papiery wartościowe) kredytów bankowych, oraz obligacje powstałe w wyniku sekurytyzacji kredytów hipotecznych (w tym subprime, czyli kredytów poniżej standardu) - MBS (mortgage based securities) - obarczone były od samego początku najwyższym ryzykiem niespłacalności ${ }^{28}$.

Wobec powyższego zasadne jest pytanie: czy wszystkie wymienione cztery formy działań państw były w rzeczywistości potrzebne? Pytanie takie zadawali sobie w różnych państwach zarówno politycy, jak i ekonomiści. Wskazywano przy tym, iż niekiedy wspomniane działania władz państwowych były wynikiem nacisku instytucji finansowych: banków, firm ubezpieczeniowych, a nawet instytucji samorządu terytorialnego (USA, Wielka Brytania, Niemcy) ${ }^{29}$. Z drugiej strony podkreślić należy, iż również politycy przestraszyli się odpowiedzialności, jaka na nich spadnie, jeśli nie podejmą stosownych działań (czyli tych sugerowanych przez finansistów, którzy zręcznie „grali” na podobnych obawach), a kryzys dotknie w szerszym

27 W. Nawrot, Globalny kryzys finansowy XXI wieku: przyczyny, przebieg, skutki, prognozy, CeDeWu.pl Wydawnictwa Fachowe, Warszawa 2009, s. 131.

28 Por. A. Sławiński, Przyczyny i konsekwencje kryzysu na rynku papierów wartościowych emitowanych przez fundusze sekurytyzacyjne, „Bank i Kredyt” 2007, nr 8-9, s. 12-17. W konwencji bardziej popularnej problematyka ta została przedstawiona w książce M. Lewisa, Wielki szort: mechanizm maszyny zagłady, przeł. K. Man, Wyd. Sonia Draga, Katowice 2011.

${ }^{29}$ Wiele z organów wykonawczych samorządów miast czy innych jednostek samorządu terytorialnego zaangażowało na rynkach finansowych znaczne sumy pieniędzy, lokując je na korzystnie oprocentowanych rachunkach lub kupując „bezpieczne” papiery wartościowe, np. obligacje. W 2008 r. jednak, kiedy zamarły transakcje na rynkach międzybankowych (kryzys płynności), wiele funduszy inwestycyjnych zaczęło ponosić straty, a "bezpieczne” papiery okazały się z dania na dzień niewiele warte. Odczuło to m.in. ponad 100 brytyjskich jednostek samorządu terytorialnego (parafii, dystryktów, hrabstw i miast), które zainwestowały w bankach islandzkich, szczególnie w IceSave, powiązanym z Landsbanki, ponad $840 \mathrm{mln}$ funtów. Hrabstwo Kent zdeponowało najwięcej, ok. 50 mln funtów, a zarząd transportu miejskiego w Londynie ok. $40 \mathrm{mln}$ funtów. Na liście depozytariuszy znalazły się brytyjskie organizacje policyjne, straż pożarna, instytucje charytatywne, a także uniwersytety brytyjskie i amerykańskie. 
wymiarze ich szeregowych wyborców (USA, Niemcy, Francja). Część decyzji z perspektywy czasu okazała się pochopna i zbyt daleko idąca, a ich negatywne skutki będą dużo poważniejsze dla społeczeństw (patrz: ruchy Oburzonych), niż politycy pierwotnie zakładali.

$\mathrm{W}$ trakcie podejmowania istotnych decyzji politycy działali w sytuacji ograniczonej informacji płynącej z rynku (np. nikt nie był w stanie określić rzeczywistej wartości tzw. toksycznych aktywów), a ponadto występował pewien rodzaj paniki moralnej, poczucia, iż stało się coś złego i należy temu niezwłocznie zaradzić. Również decyzje niektórych banków lub instytucji finansowych wskazywały na zagubienie w nowej sytuacji (np. Bank Anglii po upadku Northern Rock zmienił nagle swoją politykę o 180 stopni, podnosząc gwarancje dla depozytów z 35 tys. GBP na osobę lub instytucję do 50 tys. GBP, co wcześniej zdecydowanie krytykował i od czego się stanowczo odżegnywał; po problemach z wypłacalnością depozytów z islandzkiego IceSave gwarantował depozyty do pełnej wysokości). Nie należy więc dziwić się, iż w poszczególnych państwach władza wykonawcza (przeważnie rządy), wspólnie $\mathrm{z}$ bankami centralnymi, oraz parlamenty podejmowały określone decyzje, niejako ad hoc określając ich niezbędność w stosunku do różnych przejawów sytuacji kryzysowej, które ujawniały się w innym czasie. Jednak za podstawowe formy interwencji władz państwowych na rynku finansowym w warunkach kryzysu uznać należy wspomniane wyżej cztery formy, które w różnym wymiarze finansowym wystąpiły w kilkudziesięciu państwach.

$\mathrm{W}$ odniesieniu do pierwszego z tych działań - podtrzymania płynności na rynku międzybankowym - przykładowo w Norwegii, za aprobatą parlamentu, rząd i bank centralny podjęły decyzję o uruchomieniu funduszy w wysokości 55,4 mld dol. z przeznaczeniem dla 4 największych banków komercyjnych. Zaproponowały także bankom obligacje rządowe, w zamian za zagrożone zobowiązania z tytułu kredytów hipotecznych. W Szwecji, przy współdziałaniu podobnych podmiotów, podjęto decyzję o wprowadzeniu programu "naprawczego" o wartości $205 \mathrm{mld}$ dol. w celu przywrócenia płynności na rynku finansowym.

W kwestii gwarantowania wypłaty depozytów złożonych w bankach przez obywateli np. w Finlandii podniesiono kwotę depozytów objętych gwarancjami rządu (inaczej: gwarancjami państwa) z 25 do 50 tys. euro, zgodnie z rekomendacją przyjętą w UE. W Szwecji kwotę gwarantowanych depozytów podniesiono do 500 tys. koron szwedzkich, tj. 69 tys. dol., a dodatkowo rozszerzono zasięg gwarancji depozytowych dla obywateli, którzy powierzyli swoje środki finansowe bankom w innych państwach. Na wypadek ich niewypłacalności, miały być one zagwarantowane w równoważnej wysokości. W Danii gwarancjami rządowymi objęto depozyty we wszystkich bankach na terytorium państwa do ich pełnej wysokości i stworzono 
w tym celu fundusz o wartości ponad 6,5 mld dol. Będąca w bardzo trudnej sytuacji Irlandia objęła gwarancjami rządowymi wszystkie depozyty znajdujące się w 6 największych bankach w tym państwie, co znacznie uspokoiło nastroje klientów banków, na których także oddziaływała sytuacja w Wielkiej Brytaniii ${ }^{30}$.

We wszystkich tych przedsięwzięciach bezpośredni lub pośredni udział brały parlamenty wspomnianych państw, a podjęcie ostatecznych decyzji odbywało się często po burzliwych obradach. Powszechne jednak było przekonanie o konieczności ratowania systemu bankowego, gdyż upadek dużej liczby banków mógłby doprowadzić do katastrofy, której rozmiarów nie sposób było ocenić. Takie hiobowe scenariusze rodziły się przede wszystkim w środowisku bankowo-finansowym, które wszelkimi sposobami walczyło o swoje przetrwanie. Część badaczy i specjalistów zarówno w USA, jak i w Europie odnosiła się sceptycznie do konieczności i skuteczności podejmowanych przez organy państwa działań. Przykład Islandii pokazuje, podobnie jak obecnie przykład Grecji, że elity polityczne nie były przygotowane na rozwój zjawisk kryzysowych i nie miały przygotowanych scenariuszy postępowania.

\subsection{Podniesienie sprawności decyzyjnej parlamentów}

W warunkach kryzysowych zarówno wydarzenia wewnętrzne, jak i zewnętrzne, pochodzące $z$ otoczenia międzynarodowego, znacznie przyspieszają. Trudno więc się dziwić, że zasadnicze decyzje dotyczące działań mających ograniczać negatywne oddziaływania zjawisk kryzysowych na społeczeństwa podejmowane są głównie przez organy władzy wykonawczej. W przypadku Stanów Zjednoczonych zasadnicze kompetencje w tym względzie posiada prezydent oraz administracja federalna, a wśród niej Departament Skarbu USA i Komisja Rynku Kapitałowego (Securities and Exchange Commission, SEC). W warunkach amerykańskich pierwszoplanową rolę odgrywał również FED, który w trakcie przygotowywania decyzji współpracował z bankami centralnymi innych państw, w tym: Kanady, Wielkiej Brytanii, Japonii, Australii, Szwajcarii, Danii, Szwecji, Norwegii oraz z Europejskim Bankiem

\footnotetext{
$30 \mathrm{Na}$ aspekt zapobieżenia panice i zachowaniom „stadnym” zwraca się uwagę w wielu opracowaniach z zakresu ekonomii behawioralnej, por. m.in. G.A. Akerlof, R.J. Shiller, Zwierzęce instynkty: czy ludzka psychika napędza globalna gospodarkę i jaki to ma wptyw na przemiany światowego kapitalizmu?, przeł. J. Jannasz, Wyd. Studio Emka, Warszawa 2010. W Wielkiej Brytanii panika nastąpiła w związku z kłopotami z płynnością islandzkiego banku Landsbanki, do którego należał internetowy bank depozytowy IceSave, który wysokimi odsetkami przyciągnął ponad 300 tys. klientów brytyjskich. W latach 2007-2008 wpłacili oni depozyty o wartości ponad 4,7 mld funtów. Wyraźna panika wybuchła 3 i 4 października 2008 r., kiedy to w ciągu dwóch dni (w piątek i sobotę przy 24-godzinnym dostępie do depozytów) depozytariusze IceSave wypłacili odpowiednio: $200 \mathrm{mln}$ i $300 \mathrm{mln}$ funtów. Sytuacja ta przypieczętowała upadek banku. Por. Á. Jónsson, Why Iceland? How one of the world's smallest countries become the meltdown's biggest casualty, McGraw-Hill, New York, San Francisco, London 2009, s. 151.
} 
Centralnym. Wspólne przedsięwzięcia dotyczyły m.in. umów o wzajemnych liniach swapowych z poszczególnymi bankami centralnymi. Początkowo umowy te miały charakter czasowy, określały górną granicę transakcji swapowych, lecz z czasem i w szczególnych przypadkach nie zawierały żadnych ograniczeń, np. umowy z Bankiem Anglii, Narodowym Bankiem Szwajcarii czy Europejskim Bankiem Centralnym ${ }^{31}$.

Kongres Stanów Zjednoczonych, mimo dwuizbowej struktury i skomplikowanych procedur legislacyjnych, funkcjonował w miarę sprawnie, co w dużej mierze należy zawdzięczać stałym komisjom obu izb. To w nich bowiem toczyła się merytoryczna debata, szczególnie w odniesieniu do podstawowego dokumentu, wspomnianej ustawy The emergency economic stabilization act of 2008, podpisanej przez prezydenta USA 3 października 2008 r. i zawierającej upoważnienia dla innych organów państwa, głównie Departamentu Skarbu ${ }^{32}$. W ramach ustawy znalazły się trzy główne działy: 1) program pomocy dla zagrożonych aktywów (troubled assets relief program) - najbardziej obszerny, zajmujący 35 rozdziałów, 2) postanowienia dotyczące budżetu (budget-related provisions) oraz 3) postanowienia dotyczące podatków (tax provisions $)^{33}$. Nie tylko treść, ale i szybki tryb uchwalenia ustawy wzbudziły jednak znaczące kontrowersje w samym Kongresie. Wskazywano na łamanie procedur legislacyjnych przez przedstawicieli Partii Republikańskiej w Kongresie, podając jako przeciwwagę przykład przygotowania i uchwalenia kilkudziesięciu ustaw stanowiących podstawę prawną New Deal przez Kongres USA w 100 dni, które odbyły się bez łamania i naciągania procedur.

W sąsiedniej Kanadzie prace związane z prawnym przygotowaniem działań zmierzających do stabilizacji w sektorze finansowym oraz wzmocnienia finansowego przedsiębiorstw gospodarki realnej i konsumentów odbywały się w dużo bardziej uporządkowany sposób ${ }^{34}$. Może dlatego, że odbywały się one nieco później,

31 Por. W. Nawrot, Globalny kryzys finansowy XXI wieku..., op.cit., s. 147-148. W sumie Rezerwa Federalna zawarła umowy z 14. bankami, z których największa była umowa z EBC. Każda umowa miała charakter wzajemny i składała się z dwóch transakcji. Pierwsza polegała na tym, że gdy dany bank centralny otrzymywał od banku rezerwy federalnej (Federal Reserve Bank of New York) środki pieniężne w dolarach, wówczas sprzedawał Rezerwie Federalnej własną walutę (euro, franki szwajcarskie, korony szwedzkie czy jeny) po kursie rynkowym obowiązującym w momencie sprzedaży. Druga transakcja była odwróceniem pierwszej i realizowano ją po upływie określonego czasu, np. 30 dni. Kurs dolar - dana waluta był w drugiej transakcji taki sam, jak w pierwszej. Szerzej patrz: B. Samojlik, Polityka monetarna Rezerwy Federalnej w warunkach kryzysu, w: Wymiary kryzysu..., op.cit., s. 82 i nast.

32 Rozdział 2 ustawy: Cele (Section 2. Purposes) zasadniczy jej cel formułuje następująco: „Celem ustawy jest wyposażenie Sekretarza Skarbu we wszelkie uprawnienia konieczne do przywrócenia płynności i stabilności systemu finansowego USA".

33 The emergency economic stabilization act of 2008, Public Law, 110-343, Div. A, enacted October 3, 2008.

${ }_{34}$ Por. I. Zawiślińska, Kanada - przyjazny wymiar kryzysu, w: Państwa narodowe wobec kryzysu ekonomicznego..., op.cit., s. 103-132. 
to jest na przełomie 2008 i 2009 r., i można było skorzystać z doświadczeń amerykańskich. Wynikało z nich m.in., że zasadniczą rolę w planowanych przedsięwzięciach powinien odgrywać bank centralny i rząd, zwłaszcza ministerstwo finansów. Ale również dlatego, iż sytuacja w kanadyjskim sektorze bankowym i realnej gospodarce była znacznie korzystniejsza niż w USA.

Pewne obawy jednak istniały i wynikały po pierwsze $z$ tego, iż w realnej gospodarce sektorami najbardziej dotkniętymi przez kryzys były w 2008 r. przemysł samochodowy i branża budowlana, a tym samym pośrednio przemysł drzewny. „Wszystkie one stanowią ważny składnik kanadyjskiej gospodarki, zarówno ze względu na wartość dodaną, jak i oddziaływanie na popytową stronę rynku pracy. Niekorzystne zjawiska mogły zatem przyczynić się do wzrostu stopy bezrobocia, zwiększenia obciążeń finansów publicznych wydatkami socjalnymi, obniżenia poziomu dobrobytu społeczeństwa, a w konsekwencji poważnych problemów społeczno-gospodarczych" ${ }^{35}$. Po drugie, wynikały z postrzegania "gospodarki kanadyjskiej jako składowej procesów zachodzących w gospodarce amerykańskiej, można było oczekiwać, że kryzys finansowy będzie stanowił zagrożenie także dla stabilności kanadyjskiego systemu finansowego [...], potencjalne zaburzenia na kanadyjskim rynku finansowym mogły i ewentualnie mogą zaistnieć nie ze względu na słabe podstawy i niewłaściwe praktyki, lecz ze względu na tzw. efekt domina i łączenie obu gospodarek"36.

Podstawą prawną „ekonomicznego planu działania” (Canada's economic action plan), przyjętego przez rząd konfederacji premiera Stephena Harpera, była nowelizacja budżetu na rok 2008-2009 dokonana przed końcem 2008 r., dzięki której wyasygnowano w budżecie dodatkowe środki na priorytetowe działania związane z zapobieganiem negatywnym skutkom kryzysu oraz pobudzenie gospodarki realnej i jej modernizację. Dzięki tej nowelizacji można było wykorzystać środki w ramach planu rządowego już z początkiem 2009 r. Należy bowiem pamiętać, że rok budżetowy w Kanadzie rozpoczyna się 1 kwietnia i trwa do 31 marca następnego roku. Jednocześnie przyspieszono prace nad ustawą budżetową na lata 2009-2011, która zwyczajowo uchwalana była w końcu lutego przed rozpoczęciem roku budżetowego, bowiem w kanadyjskim prawie konstytucyjnym nie występuje termin „prowizorium budżetowe". Ostatecznie ustawę budżetową uchwalono 27 stycznia 2009 r., czyli około miesiąca wcześniej, niż wymagają tego obowiązujące regulacje prawne. Dodatkowo skrócono do miesiąca (zamiast okresu od 2 do 6 miesięcy) czas na zaakceptowanie przez instytucje wykonawcze rządu federalnego działań zawartych w planie.

\footnotetext{
35 Ibidem, s. 104-105.

36 Ibidem, s. 105-106.
} 
W przypadku Kanady takie skracanie terminów i upraszczanie procedur odbyło się zgodnie z regulacjami prawnymi i zwyczajami konstytucyjnymi i parlamentarnymi. Zdecydowaną przewagę $\mathrm{w}$ procedurze stanowienia ustawy budżetowej posiada Izba Gmin i to w jej komisjach stałych odbywają się zasadnicze debaty merytoryczne z udziałem przedstawicieli rządu i ekspertów ${ }^{37}$. Stąd również, obok przekonania parlamentarzystów o niezbędności działań naprawczych i prorozwojowych, wynikała wysoka skuteczność działania parlamentu kanadyjskiego w warunkach kryzysu.

W Europie duże zaangażowanie parlamentów w przyjęcie podstaw prawnych dla programów stabilizacyjnych i interwencyjnych władz wykonawczych można było obserwować w całym roku 2008 oraz 2009. Dotyczy to szczególnie brytyjskiej Izby Gmin, francuskiego Zgromadzenia Narodowego, niemieckiego Bundestagu, a także izb niższych parlamentów w Irlandii, Belgii i Holandii. Inne z kolei parlamenty, ze względu na występującą w nich większość parlamentarną opartą na doktrynalnych kryteriach ideologicznych oraz powołane przez tę większość rządy niepotrafiące w porę sformułować właściwych antykryzysowych propozycji ustawodawczych, zajęły pozycje defensywne. Przykładami są parlamenty grecki, hiszpański czy włoski.

Ze względu na to, iż wspomniane państwa znajdują się w strefie euro, negatywne skutki ekonomiczne i finansowe pewnej opieszałości i zaniechań z ich strony wpłyną także na pozostałe państwa UE, w tym Polskę. W świetle już podejmowanych działań pomocowych dla Grecji problem ten ma charakter dynamiczny i będzie się rozwijał, a ze względu na kryteria bankructwa państw, przyjęte w literaturze ekonomicznej i politologicznej ${ }^{38}$, Grecja już jest bankrutem. Zwlekanie z prawnym ogłoszeniem jej upadłości zarówno przez UE, jak i samą Grecję ma pozwolić EBC, bankom prywatnym oraz innym państwom i instytucjom UE przygotować się na ten fakt, aby minimalizować jego skutki (patrz: decyzje Szczytu Europejskiego w Brukseli 26 października 2011 r. czy późniejsze podpisanie tzw. paktu fiskalnego). „W inny sposób definiuje się także samo pojęcie bankructwa, które przykładowo w odniesieniu do banku lub innej instytucji finansowej oznacza, iż utraciła ona płynność finansową i nie jest w stanie realizować swoich zobowiązań wobec podmiotów krajowych

37 Ekonomiczny plan działania, dla realizacji którego w ustawie budżetowej zagwarantowano prawie 62 mld dolarów kanadyjskich w ciągu dwóch lat budżetowych (2009-2010 i 2010-2011), określa sześć podstawowych obszarów działań. Są nimi: 1) redukcja obciążeń podatkowych, 2) pomoc bezrobotnym, 3) budowa infrastruktury w celu stworzenia nowych miejsc pracy, 4) budowa gospodarki przyszłości, 5) wsparcie przemysłu i społeczności lokalnych, 6. poprawa dostępności do finansowania i umocnienie kanadyjskiego systemu finansowego. Należy zwrócić uwagę na hierarchię obszarów w ramach planu. Działania odnoszące się do systemu finansowego znalazły się w dalszej kolejności niż działania nakierowane na obywateli - podatników, pracobiorców i konsumentów czy działania na rzecz wsparcia gospodarki realnej. Szerzej patrz: I. Zawiślińska, Kanada - przyjazny wymiar kryzysu..., op.cit., s. 114-123.

38 Por. C.M. Reinhard, K.S. Rogoff, This time is different: eight centuries of financial folly, Princeton University Press, Princeton, Oxford 2009. 
i/lub międzynarodowych, co oznacza, że jej interesariusze ponoszą ewidentne straty. W przypadku konkretnych państw uznaje się, iż bankructwo (faktyczna niewypłacalność, bez konieczności jej deklaratywnego potwierdzenia przez władze danego państwa) to sytuacja, w której państwo zawiesza lub choćby zmienia warunki spłaty zobowiązań krajowych i/lub zagranicznych na mniej korzystne dla wierzycieli. Co oznacza, iż państwo zamierza oddać mniej niż wynosi dług lub w innych terminach niż zostały ustalone, albo w grę wchodzi jedno i drugie"39.

\subsection{Zwiększenie zakresu i instrumentów działalności kontrolnej}

Równie wysoką skuteczność w przeciwdziałaniu negatywnym skutkom kryzysu wykazały w Europie parlamenty skandynawskie, które dzięki skoordynowanym działaniom w 2008 i w 2009 r. zdołały uchronić swoje systemy bankowe i realną gospodarkę. Bardzo ważną rolę odegrała także współpraca rządów i banków centralnych Danii, Szwecji i Norwegii, państw o zróżnicowanej sytuacji politycznej i ekonomiczno-finansowej. Dania i Szwecja, będąc członkami Unii Europejskiej, pozostają poza strefą euro, gdyż zachowują swoje waluty narodowe. W przypadku Szwecji można mówić o wysoce rozwiniętym systemie bankowo-finansowym zaangażowanym regionalnie (szczególnie w państwach bałtyckich: Estonia, Łotwa, Litwa i w państwach Europy Środkowej, w tym w Polsce) i globalnie, z silnym i niezależnym bankiem centralnym. W Danii jest podobnie, choć ekspansja zewnętrzna duńskiego systemu bankowo-finansowego jest mniejsza, mimo że w wymiarze regionalnym istotna (szczególnie bliskie związki z bankami islandzkimi: Landsbanki, Kaupthing i Glitnir spowodowały nieoczekiwane zagrożenie po ich upadku na przełomie września i października 2008 r.). Norwegia, pozostając poza UE i posiadając walutę narodową, jest jednak państwem Europejskiego Obszaru Gospodarczego, co nakłada na nią pewne obowiązki w zakresie standaryzacji rynku bankowego i finansowego. Jedynie Finlandia pozostaje pełnoprawnym członkiem Unii Gospodarczej

\footnotetext{
39 J. Osiński, Niezbędność państwa $w$ dobie globalizacji oraz jego współczesne modele, w: Wspótczesne państwo w teorii i praktyce..., op.cit., s. 703-704. Podejmowane przez rząd b. premiera Georgiosa Papandreu próby przeprowadzenia ogólnonarodowego referendum w sprawie „przyjęcia” przez Grecję kolejnego pakietu pomocowego i ewentualnego pozostania kraju w strefie euro zmierzają do przeniesienia odpowiedzialności z władz na greckie społeczeństwo. Z drugiej strony chodzi o uczynienie z państw Eurolandu, głównie Niemiec i Francji, „współwinnych” zaistniałej sytuacji. Każdy bowiem rezultat referendum, pozytywny czy negatywny, byłby perspektywicznym sukcesem wspomnianego rządu. Stąd bardziej prawdopodobna stała się jego zmiana poprzez wotum nieufności, choć nie odbyło się bez dwukrotnych przedterminowych wyborów do parlamentu!
} 
i Walutowej, co powoduje podporządkowanie systemu bankowego EBC oraz dyrektywom finansowym $\mathrm{UE}^{40}$.

W 2008 r. wszystkie wspomniane państwa (Dania, Szwecja i Norwegia) skorygowały swoje regulacje dotyczące budżetów państwa, aby umożliwić rządom i bankom centralnym podjęcie środków zaradczych wobec narastających zjawisk kryzysowych i zagrożeń, jakie pojawiły się w systemach finansowych i w realnej gospodarce. Realizację nowych działań wynikających ze zmian w budżetach przekazano władzom wykonawczych (rządom), jednak ze względu na koszty tych działań, zobowiązano rządy do ścisłej współpracy $\mathrm{z}$ bankami centralnymi. Jedynie w Finlandii, która jest członkiem strefy euro, aktywność władz wykonawczych polegała na wdrażaniu przedsięwzięć podejmowanych przez EBC.

Od uporządkowanego modelu współdziałania władz wykonawczych z bankami centralnymi wspomnianych państw zdecydowanie odbiega sytuacja władz w Islandii, w której rozmiary kryzysu są najbardziej dotkliwe ${ }^{41}$. Dlatego trudno się dziwić, iż sięgnięto tu po szczególne procedury, w ramach których podjęto próbę określenia przyczyn kryzysu, przyjęcia nowych regulacji prawnych wzmacniających system bankowo-finansowy i zabezpieczających interesy państwa i obywateli oraz pociągnięcia do odpowiedzialności osób szczególnie winnych zarówno złych decyzji, jak i zaniechań w dokonywaniu zmian. Jedną z form realizacji wspomnianych procedur zaradczych było powołanie parlamentarnej komisji śledczej. Do jej zadań należało określenie przyczyn upadku islandzkiego systemu bankowego, a co za tym idzie bankructwa Islandii, jak również wskazanie instytucji i osób odpowiedzialnych za brak nadzoru nad systemem bankowym oraz za zaniechania i błędy władzy wykonawczej (szczególnie premiera Geira Hilmara Haardego i ministra finansów Árniego Mathiesena) i Banku Islandii (szczególnie jego prezesa Davíða Oddsona). Najogólniej można stwierdzić, że komisja dobrze wywiązała się ze swojego zadania,

$40 \mathrm{~W}$ prezentowanej analizie pominięto fakt, iż parlamenty państw skandynawskich (z wyjątkiem Norwegii o zmodyfikowanym parlamencie jednoizbowym) mają strukturę jednoizbową, co powoduje, że są efektywniejsze w podejmowanych działaniach nie tylko w warunkach kryzysu. Zauważyć należy, iż sprawność funkcjonowania parlamentów skandynawskich w tych szczególnych warunkach wyraźnie wskazuje na silny związek między ich jednoizbowością a skutecznością reakcji (szybkością, kompetentnością i jednoznacznością). Por. J. Osiński, Transformacja ustrojowa w Europie a struktura parlamentów: nowoczesność czy anachronizm?, w: Europa w gospodarce, polityce i kulturze światowej: między dziedzictwem i przyszłością, red. J. Osiński, Oficyna Wydawnicza SGH, Warszawa 2004, s. 281-295.

41 O przyczynach „islandzkiej katastrofy” patrz: L. Kukliński, Bankowość islandzka - bankructwo systemu?, w: Międzynarodowe bankructwa i afery bankowe, red. P. Masiukiewicz, Oficyna Wydawnicza SGH, Warszawa 2010 oraz J. Osiński, Przemiany polityczne na Islandii w warunkach kryzysu bankowego i gospodarczego, „Kwartalnik Kolegium Ekonomiczno-Społecznego. Studia i Prace” 2011, nr 1(5), Oficyna Wydawnicza SGH, s. 13-45. 
przedstawiając obszerny raport pt. Przyczyny upadku banków islandzkich - odpowiedzialność, błędy i zaniechania ${ }^{42}$.

Innym novum, które w trakcie kryzysu ekonomicznego 2007+ nie znalazło zastosowania w żadnym innym państwie, było skorzystanie $\mathrm{z}$ instytucji referendum. W Islandii odbyło się ono dwukrotnie i dotyczyło podobnej kwestii, tzw. sprawy IceSave. Interesująca była jego problematyka i to, że rozstrzygnęło ono ostatecznie różnicę stanowisk w podejściu do kwestii zwrotu depozytów obywatelom Wielkiej Brytanii i Holandii złożonych w islandzkim banku internetowym Ice Save, powiązanym $z$ jednym $z$ trzech największych banków Landsbanki. Ten ostatni, na fali działań zapobiegawczych wobec kryzysu, został przyjęty przez państwo. „Na fali paniki, jaka ogarnęła Brytyjczyków i Holendrów posiadających depozyty w IceSave, instytucje nadzorujące rynki finansowe w tych państwach podjęły decyzje o wypłatach swoim obywatelom $\mathrm{z}$ bankowych funduszy gwarancyjnych depozytów utraconych po zawieszeniu wypłat, a w zasadzie po upadku Landsbanki. Nacjonalizacja banku w dniu 8 października 2008 r. niewiele zmieniła sytuację, bowiem Bank Centralny Islandii nie był w stanie zagwarantować środków finansowych na pokrycie masowego wycofywania wkładów z IceSave. «Grzechem pierworodnym» w tej sytuacji był fakt, iż brytyjski Financial Services Compensation Scheme (FSCS) wraz z Ministerstwem Skarbu ustaliły, iż wypłaty dla obywateli brytyjskich z funduszu gwarancyjnego będą wypłacane, po pierwsze do pełnej wysokości depozytów, a po drugie nie konsultowały tej decyzji z władzami islandzkimi, które stały od początku na stanowisku, iż są zobowiązane prawnie (wspomniana Dyrektywa 94/19/EEC) do wypłaty gwarancji minimalnych do wysokości 20887 euro na jeden depozyt. Z kolei władze holenderskie początkowo przyjmowały za podstawę wypłatę gwarancji minimalnych, a następnie pod naciskiem właścicieli depozytów, podjęły decyzję o podniesieniu wypłat z funduszu gwarancyjnego do 100 tys. euro. Społeczeństwo islandzkie i część polityków obie te decyzje, brytyjską i holenderską, potraktowało jako nie powodujące skutków finansowych dla Islandii. Były to wewnętrzne decyzje wspomnianych państw w relacjach z ich obywatelami, stroną których nie były oficjalne organy islandzkiego państwa, bowiem one nie zostały nawet wcześniej o nich poinformowane"43.

W związku z tym, iż sprawa była bardziej złożona trzy zainteresowane państwa podjęły negocjacje. Wcześniej, na podstawie tzw. wytycznych brukselskich, Alpingi przyjęło 5 grudnia 2008 r. uchwałę zobowiązującą rząd islandzki do negocjacji

42 Jest to liczący ponad 200 stron dokument przyjęty ostatecznie przez Alpingi w 2010 r., którego analiza wykracza poza niniejsze opracowanie. Powinien on być jednak wnikliwie przestudiowany przez decydentów politycznych i finansowych kierujących na różnych szczeblach bankami i instytucjami finansowymi. s. 35 .

${ }^{43}$ J. Osiński, Przemiany polityczne na Islandii w warunkach kryzysu finansowego i gospodarczego, op.cit., 
i zawarcia porozumienia w kwestii spłaty zobowiązań powstałych po upadku IceSave. „Zasadniczym dążeniem strony brytyjskiej i holenderskiej było zobowiązanie się państwa islandzkiego do uczestniczenia w spłacie długów powstałych $\mathrm{w}$ rezultacie upadku IceSave, ale także nacjonalizacji Landsbanki. Zarówno bank, jak i IceSave były wcześniej instytucjami prywatnymi, wobec czego nie mogło być mowy o udziale państwa w spłacaniu ich długów, chyba że wolę taką wyraziłby islandzki parlament. Także, jak wspomniałem, prywatny charakter miał Islandzki Fundusz Gwarancyjny Depozytariuszy i Inwestorów, wobec czego jego zobowiązania wobec podobnych instytucji w Wielkiej Brytanii czy Holandii, jak również władz państwowych nie miały mocy wiążącej dla rządu i parlamentu islandzkiego"44.

Wynegocjowane porozumienia mogły wejść $\mathrm{w}$ życie dopiero po przyjęciu stosownej ustawy w Alpingi, zgodnie z art. 40 Konstytucji Islandii. Stosowny projekt ministerstwa finansów został wniesiony pod obrady 30 czerwca 2009 r. jako projekt ustawy nr 96/2009 i wywołał burzliwe debaty. Ostatecznie parlament, po dyskusjach w komisjach stałych i na podstawie rekomendacji Komisji Budżetu z 15 sierpnia $2009 \mathrm{r}^{45}$, przyjął 28 sierpnia $2009 \mathrm{r}$. ustawę $\mathrm{nr}$ 96/2009, zawierającą upoważnienie w sprawie dla ministra finansów. Po aprobacie przez rządy Wielkiej Brytanii i Holandii i podpisaniu dokumentów 19 października 2009 r. sprawę przekazano ponownie do parlamentu, by uchwalił ustawę o wejściu w życie porozumień. Stało się to 30 grudnia 2009 r., po niemal dwumiesięcznych debatach. Parlament uchwalił ustawę nr 1/2010, zmieniająca ustawę nr 96/2009 z 28 sierpnia 2009 r., „dotyczącą upoważnienia dla Ministra Finansów w imieniu Skarbu Państwa do przyznania gwarancji państwa dla pożyczek udzielonych przez rządy Wielkiej Brytanii i Holandii Islandzkiemu Funduszowi Gwarancyjnemu Depozytariuszy i Inwestorów, przeznaczonych na pokrycie wypłat dla depozytariuszy Landsbanki Íslands hf”"

Sprawa się nie zakończyła, bowiem prezydent Islandii Ólafur Ragnar Grimsson, który powinien podpisać ustawę, ogłosił 5 stycznia 2010 r., iż nie zamierza tego uczynić. Oznaczało to konieczność przeprowadzenia ogólnonarodowego referendum w sprawie obowiązywania ustawy. Pozytywny wynik takiego referendum zadecydowałby o uzyskaniu przez nią mocy obowiązującej. W przeciwnym wypadku nie wchodziłaby ona $\mathrm{w}$ życie. Termin referendum $\mathrm{w}$ sprawie IceSave wyznaczono na 6 marca 2010 r. Sondaże przed referendum wskazywały na ogromną przewagę przeciwników uchwalonej ustawy. Zorganizowali oni wiele akcji

44 Ibidem, s. 36

45 Tekst rekomendacji Komisji Budżetu Alpingi z 15 sierpnia 2009 r. patrz: www.island.is (dostęp: wrzesień 2011 r.).

46 Por. J. Osiński, Przemiany polityczne na Islandii w warunkach kryzysu finansowego i gospodarczego, op.cit., s. 38. Ustawa jest nazywana w skrócie „ustawą o IceSave”. 
zachęcających do sprzeciwu wobec rozwiązania narzucającego wszystkim obywatelom spłatę zobowiązań powstałych w rezultacie niekompetentnych działań przedstawicieli establishmentu bankowego i polityków. Zaktywizowały się portale społecznościowe, nieformalne grupy przeciwników ustawy i organizacje pozarządowe, a przede wszystkim Ruch w Obronie Islandii (InDefence of Iceland), który powstał już w 2008 r. w odpowiedzi na nieprzyjazne kroki władz brytyjskich w stosunku do Landsbanki. Wynik referendum był więc nieformalnie znany, choć skala sprzeciwu była nie do przewidzenia.

Po przeliczeniu głosów i ogłoszeniu ostatecznych wyników okazało się, iż przewaga przeciwników wejścia w życie omawianej ustawy była przygniatająca. Spośród 144231 wyborców, którzy wzięli udział w referendum, aż 134 397, czyli 93,2\%, opowiedziało się przeciwko ustawie. Tylko 2599 uczestników referendum, czyli 1,8\%, zaaprobowało jej wejście w życie. Czyste karty do głosowania oddało 6744 wyborców, czyli 4,7\%, zaś 491 kart oddanych, czyli 0,3\%, było nieważnych. Frekwencja jednak, jak na warunki Islandii, nie była zbyt wysoka i wyniosła $62,72 \%{ }^{47}$. W ten sposób doszło w warunkach kryzysu do wyraźnej sprzeczności i konfliktu pomiędzy parlamentem, wyłonionym $w$ ramach mechanizmów demokracji przedstawicielskiej, a opinią wyrażoną przez społeczeństwo przy wykorzystaniu instytucji demokracji bezpośredniej, tj. referendum.

Wyniki referendum wywołały największą reakcję w państwach bezpośrednio zaangażowanych w sprawę, a przedstawiciele rządów Wielkiej Brytanii i Holandii wyrazili swoje „rozczarowanie”, ale także wolę powrotu do stołu rokowań, co rząd islandzki przyjął z zadowoleniem. Ostatecznym rezultatem nowych negocjacji były porozumienia, które zawierały znacznie korzystniejsze warunki dla strony islandzkiej. M.in. okres zwrotu miał być wydłużony do 30 lat i obejmować lata 2016-2046, znacząco zmalało oprocentowanie długu: w przypadku Wielkiej Brytanii miało wynosić 3,3\%, zaś w przypadku Holandii - 3,0\%. Inaczej sformułowano także zobowiązania strony islandzkiej, co zapisano w nowej ustawie uchwalonej przez Alpingi 16 lutego 2011 r., a więc 11 miesięcy po pierwszym referendum.

I tym razem konsekwentnie prezydent Ólafur Ragnar Grimsson nie promulgował ustawy, co poskutkowało przekazaniem jej pod ogólnonarodowe referendum, zgodnie z art. 26 Konstytucji Islandii. Odbyło się ono 9 kwietnia 2011 r., a kampania przed nim nie była już tak burzliwa, jak przed pierwszym, za to bardziej rzeczowa. Sami Islandczycy oswoili się już z postkryzysową sytuacją, od której początku upłynęło niemal 2,5 roku. Pracę zakończyła wspomniana specjalna komisja Alpingi.

47 Por. http://www.kosning.is/english/ oraz http://icelandreview.com/icelandreview/daily_news, 6 marca 2010 r. (dostęp: maj 2011 r.). 
Te i inne wydarzenia, np. kontynuacja starań o akcesję Islandii do UE, skutkowały wyciszeniem emocji i zmniejszyły kontrowersje między stronami. Ostatecznie, w drugim referendum w sprawie IceSave wzięło udział 177559 wyborców, co dało w skali państwa frekwencję 77\%. Za przyjęciem ustawy nr 13/2011 głosowały 69462 osoby, czyli 39,7\%, przeciw było 103207 wyborców, czyli 58,9\%, 2039 kart do głosowaniach było czystych, zaś 406 głosów uznano za nieważne.

Mimo wyraźnie zmieniających się preferencji wyborców, większość Islandczyków nie zamierza uczestniczyć w regulowaniu należności powstałych poza ich kontrolą i w dużej części z winy władz brytyjskich. Dziś bowiem wiadomo, że aktywa Landsbanki, których odsprzedaż jeszcze trwa, wystarczą na pokrycie niemal 90\% roszczeń depozytariuszy z Wielkiej Brytanii i Holandii. Oznacza to, iż drastyczne działania podjęte przez władze brytyjskie nie miały uzasadnienia w rzeczywistym stanie finansów banku i były przedwczesne, bez dokładnego rozeznania sytuacji. Może więc chodziło o pozbycie się z brytyjskiego rynku finansowego niewygodnego konkurenta?

\section{Zakończenie}

Niniejszy tekst jest próbą określenia znaczenia parlamentów w podejmowaniu działań mających na celu przeciwdziałanie rozprzestrzeniania się kryzysu 2007+, jak również zapobieganie jego negatywnym skutkom dla gospodarki i społeczeństw. Powinien być jednak potraktowany jako wstęp do zagadnień, które mogą być poddane analizie w ramach tak sformułowanego tematu. Stąd nie może on pretendować do usystematyzowanej prezentacji zasadniczych problemów związanych z modernizacją funkcjonowania parlamentów w warunkach kryzysu ekonomicznego. Wstępną analizą objęto ograniczoną liczbę parlamentów (USA, Kanady i państw skandynawskich); ciekawe porównanie mogłoby dotyczyć np. Polski. Jednak we wszystkich przypadkach należy stwierdzić znaczne zaangażowanie parlamentów i dalekie wkroczenie w materię ekonomiczną. Podobne działania państwa w warunkach stabilizacji i dobrej koniunktury spotkałyby się z potępieniem ze strony neoliberalnych fundamentalistów, którzy uznaliby je za naruszenie wyznawanej przez nich „naukowej religii”.

Zasadnicze, poważne pytanie dotyczy realnego wpływu parlamentów i możliwości ich oddziaływania na procesy zachodzące $\mathrm{w}$ gospodarce narodowej, regionalnej i globalnej. Czy ów wpływ i możliwości oddziaływania ex ante dotyczą tylko poziomu gospodarki narodowej, zaś w odniesieniu do poziomu regionalnego jest to oddziaływanie ex post $\mathrm{i}$ ex ante, a globalnego tylko ex post? Jak powinna 
przebiegać modernizacja parlamentów, aby nie stały się, nawet $\mathrm{w}$ demokracjach, instytucjami fasadowymi i bezsilnymi?

Punktem wyjścia do rozważań o ewolucji czy modernizacji współczesnych parlamentów jest kwestia charakteru współczesnego państwa. Warunki kryzysu ekonomicznego i szczególny splot wydarzeń o charakterze finansowym, gospodarczym oraz politycznym i społecznym nakazują zwrócić uwagę na problem ewolucji współczesnego państwa oraz niemal wszystkich jego organów. Oczywiście, owa ewolucja (modernizacja) odbywa się w poszczególnych państwach z różnym nasileniem i w różnym czasie, tym niemniej współczesny kryzys jest istotnym katalizatorem zmian. Z pewnością w mniejszym stopniu zmieni on funkcjonowanie instytucji państwowych w USA niż w państwach skandynawskich, gdzie państwo w systemie wartości społeczeństwa zajmuje tradycyjnie wysoką pozycję, a szkody mentalne wyrządzone przez neoliberalną retorykę i działania są stosunkowo małe.

Parlamenty pozostają podstawowymi instytucjami demokracji przedstawicielskiej. Nie oznacza to jednak, iż ich funkcjonowanie nie może ulegać modernizacji, tak w sensie funkcjonalno-organizacyjnym, jako instytucji celowej, uchwalającej dobre prawo i stojącej na straży zgodnego z prawem funkcjonowania władzy wykonawczej, jak i w sensie jednostkowym, odnoszącym się do etosu poszczególnych deputowanych czy kongresmanów. Wydarzenia kryzysu w różnych państwach wskazują, iż parlamenty, jako instytucje przedstawicielskie, nie zawsze stają po właściwej stronie (powoduje to m.in. słabe merytorycznie zaplecze eksperckie w tych zupełnie nowych kwestiach), a nawet jeśli, to nie zawsze są skłonne ponosić odpowiedzialność za podejmowane decyzje prawne. Siła i znaczenie polityczne sektora finansowego w państwach wysoko uprzemysłowionych znacznie odbiega od tego, co można określić jako „publiczna użyteczność”.

Imperializm świata finansów jest czymś więcej niż finansyzacja (finansjeryzacja) gospodarki realnej (przemysłowej, usług i rolnictwa). Jest to trend propagowany przez „neoliberalnych szamanów”, uwolniony od praktyki i teorii ekonomicznej, zmierzający do podporządkowania sobie wszystkich pozostałych sfer aktywności państw i społeczeństw, w tym polityki, prawa czy kultury. Trend wyraźnie zauważalny we współczesnych państwach wysoko rozwiniętych, jak również w niektórych państwach „peryferyjnego kapitalizmu”. Wartości współczesnej cywilizacji Zachodu ani wartości „nowego systemu gospodarowania”, sformułowane i uznawane przez Adama Smitha i jego licznych następców, nie mają z owym imperializmem nic wspólnego. 


\section{Attempts at modernization of position and workings of parliaments during crisis conditions}

The 2007+ finacial crisis, which also had an impact on real economy, paradoxically resulted in an increase of states' activity in economy and in the growth of expectations of citizens towards states. The crisis makes them see the state as the only institution able to guarantee financial and social safety as well as orderly development of global economy in future. The article tries to answer the following question: is the state able to secure that feeling of safety and society's ability to develop, and will the incoming crises influence the modification of horizontal and vertical extent of functions of the modern state? The question whether modern states modernize or not, disregarding economic, social, cultural and military crises, is also a subject of preliminary analysis.

The 2007+ economic crisis caused an increase in state activities in fields both related to economic problems and providing social and financial safety for citizens. The modernization of state institutions (the state conisdered as ontological being, i.e. is not identified with any present day state) is not related to crises. The internal institutions of state, as parliaments and executive are also modernized to a certain extent. The analyses of Scandinavian, US and Canadian parliaments included in the article prove that the parliaments use the legislative possibilities and increase the scope of control activities performed during crisis. Occasionally this leads to constitution infringement (US Congress). On other occasions special parliamentary commissions and direct democracy institutions are used (Iceland).

During a crisis a phenomenon of „financial world imperialism” emerges. It is something more than financialization of real economy (industrial, services and agriculture). It is a trend leading to the subordination of all the other spheres of activity of states and societies, including politics, law and culture. It is observed in contemporary highly developed societies as well as in some countries of "peripheral capitalism”. This trend is visible when democracy is used, including parliamentary procedures and decision-making processes in executive, to advance special interests of the financial world, its continuity and its profits. 


\section{Les tentatives de modernisation de la position et du fonctionnement des parlements face à la situation de crise}

La crise financière en $2007+$, qui a touché l'économie réelle, a conduit paradoxalement à une augmentation du rôle de l'État dans l'économie et à des exigences croissantes des citoyens envers l'État. Les citoyens perçoivent l'État comme la seule institution capable d’assurer la sécurité financière et sociale ainsi que le développement ordonné de l'économie mondiale à l'avenir. La principale question de recherche dans l'article est une tentative de déterminer si un État est en mesure d'assurer le sentiment de sécurité et les conditions pour le développement des sociétés et en outre, si de nouvelles crises économiques vont modifier les fonctions exercées par l'État moderne. L'analyse porte aussi sur la question de savoir si l'État se modernise ou non, quelle que soit la crise - économique, sociale, culturelle ou militaire.

A la suite de la crise économique de 2007+ le rôle de l'État a augmenté dans les domaines liés aux problèmes économiques et à la sécurité sociale et financière des citoyens. La modernisation des institutions de l'État, comme on le voit dans la perspective ontologique (cela signifie que l'État n'est pas identifié avec un État particulier), se déroule indépendamment de la crise. Les organes de l'État sont également soumis à la modernisation, y compris le parlement et l'exécutif. L'analyse des parlements aux États-Unis, au Canada et dans les pays nordiques prouve qu'ils savent utiliser leur pouvoir législatif et qu'ils augmentent leur pouvoir de contrôle lors de la crise, ce qui se produit parfois en violation des procédures démocratiques (Congrès américain) ou avec le recours aux comités spéciaux du parlement et aux mécanismes de démocratie directe (Islande).

La crise a révélé le phénomène de «l'impérialisme du monde de la finance», qui vise à subordonner tous les autres domaines d'activité de l'État et de la société, y compris la politique, la loi ou la culture. Il est observé dans les pays développés, ainsi que dans certains pays capitalistes périphériques. C’est une tendance qui s'exprime dans l'utilisation de la démocratie, y compris les procédures parlementaires et le processus de décision au sein de l'exécutif, dans l'intérêt étroitement conçu du monde financier, de sa stabilité et de ses profits. 